\title{
The Life and Scientific Legacy of the Outstanding Ukrainian Economist V. A. Kosynskyi (1864-1938)
}

\section{Lyubov Sukhoterina}

\author{
Odessa National Polytechnic University \\ Shevchenko Avenue 1 \\ Odessa 65044, Ukraine \\ Email: liubovsukhoterina@gmail.com
}

\begin{abstract}
The article is dedicated to the activities of the Academician of the National Academy of Sciences of Ukraine, doctor of political economy, Volodymyr Andriyovych Kosynskyi (1864-1938), who was born in Ukraine and worked in many European countries, particularly in Latvia. Kosynskyi was active as an economist, statistician, and a public and political figure, who held the position of the Minister of Labor of Ukraine from November to December 1918. The study allows to systematize and critically evaluate the sources on the impact of Kosynskyi's activities on the development of economics, as well as to reconstruct the main stages of his life and professional career. After a critical evaluation of the sources on the impact of Kosynskyi's activities in economics, it is shown that his main contribution was the following: development of methodological problems of political economy, the theory and practice of credit, and methodology to develop agriculture. Kosynskyi was among the first to proclaim the transition of statistics from a science that collects and organizes information to a science that explains and predicts. The article also presents a periodization of Kosynskyi's life and creative path, tracing the following periods: the Hlukhiv period, the Moscow period, two Riga periods, two Odessa periods, the Kyiv period, and the Czech period.
\end{abstract}

Keywords: agricultural economics, financial science, history of economic science, statistics

For many years, the life and work of Volodymyr Andriyovych Kosynskyi remained outside the focus of research because of his status as an emigrant. Only in recent years, researchers have turned to study his scientific legacy owing to his 
dedication as a scientist and a teacher. Proceedings on the impact of his activities on systematization and a critical evaluation of the sources of Kosynskyi's activities were known not only in Europe but also in America. His works have not lost their scientific significance even today (Kosynskyi, 1904; 1913; 1998; 2013; Ruda, 2010; Morozov, 2011; Bielashov, 2011; Kryzhanivskyi, 2017; Vecherskyi, 2005; Masliichuk, 2016; Eliseva \& Dmitriev, 2011; Feigmane, 2017; Matvieieva, 2012). The interest in his person has not faded, since scholars continue to emphasize his abilities and hard work on the impact of systematization and a critical evaluation of the sources of this impact as a scientist and an economist (Kosinskii, 1890; Kosynskyi, 1904; 1998; Eliseva \& Dmitriev, 2011; Feigmane, 2017; Palii, 2013; Tovmachenko, 2012; Matvieieva, 1998) and as an academician (Kosynskyi, 1913; 2018; Volobuev, 1992; Palii, 2013). His enlightened personality still captures the interest of local historians and economists. Despite the plethora of information about the impact of Kosynskyi's activities in systematization and the critical evaluation of the sources of the impact (Kosynskyi, 1904; 1913; 1998; 2013; Ruda, 2010; Morozov, 2011; Bielashov, 2011; Kryzhanivskyi, 2017; Vecherskyi, 2005; Masliichuk, 2016; Eliseva \& Dmitriev, 2011; Feigmane, 2017; Matvieieva, 2012), his activities were aimed at the development of economics in general and statistics in particular. They are described in not so great detail, but some periods of his life and work, particularly the Odessa and Riga periods (Kosynskyi, 1998; Matvieieva, 1998), have hardly been studied. In this regard, the purpose of the article is a historical analysis of the impact of his activities in systematization and a critical evaluation of the sources on this impact on the development of economic science in the Russian Empire, and tracking of academic connections between Ukraine and Latvia.

Volodymyr Andriyovych Kosynskyi was born in the village of Doroshovka, Hlukhiv uyezd, Chernihiv governorate (now a village in the Yampil district of the Sumy region) on August 13, 1864. According to other sources, he was born on the Yankov farm in the same uyezd in Ukraine, in the family of a nobleman landowner and a provincial secretary. He came from an ancient noble family, which dates back to the 14th century and the most famous representative of which was Kryshtof Kosynskyi, Hetman of the Zaporizhian Lowland Army in 1591-1593 and the leader of the Cossack uprising in the same years (Ruda, 2010).

Kosynskyi received his primary education at one of the first gymnasiums in Hlukhiv. It was a provincial school, which on August 1, 1870 was transformed into a four-grade men's grammar school, which annually enrolled 200-250 students. On July 1, 1889, the gymnasium was transformed into the Hlukhiv classical gymnasium with eight years of study. 
The gymnasium was an outstanding cultural center of the Chernihiv region (Kryzhanivskyi, 2017). It was founded with the financial support of the family of the famous philanthropist Nikola A. Tereshchenko. Tereshchenko came from a famous noble family in the Chernihiv province and had the rank of a secret adviser. He was known as a wealthy sugar grower and an active public figure.

The following subjects were included in the gymnasium's curricula: mathematics (arithmetic, algebra, geometry, and trigonometry) and languages: Russian, Latin and Greek, French; literature, physics, cosmography, geography, history, logic, psychology, law, hygiene; calligraphy, drawing, gymnastics, singing, music, and dancing, also religion in all classes for the Orthodox students (Morozov, 2011; Bielashov, 2011). The education that Kosynskyi received at the school contributed to him being later well versed in languages, as he was fluent in Russian, German, French, English and Italian.

Kosynskyi continued his education at Novgorod-Seversky Gymnasium. As a result of the imperial school reform in Novgorod-Seversky, which was the center of the governorate, the Main Public School was opened in 1789, and it was later transformed into a gymnasium. From a small gymnasium in Novgorod-Seversky in the 19th century it became one of the leading educational institutions in Ukraine. Kosynskyi graduated from this famous educational institution in 1883 (Vecherskyi, 2005; Masliichuk, 2016; Miroshnichenko \& Fedirko, 2014).

After graduating from the gymnasium he studied at the faculties of physics, mathematics and law (as an extern) of Moscow University. He received a degree in mathematics in 1887 and a law degree in 1891 (Kosynskyi, 2013, p. 51). In 1890 , Kosynskyi published his work 'On the methods of scientific development of statistical data' (Kosinskii, 1890).

In 1891, Kosynskyi left the Department of Political Economy and Statistics to prepare for a professorship for a period of two years (with the financial support of the Ministry of Education). The department was headed by A. I. Chuprov, one of the leading Russian statisticians known at the time, and a political economist and a specialist in agrarian problems. Since 1894, the period of preparation for Kosynskyi was extended for another year. In 1895, he passed the examinations for the master's degree in political economy.

In 1895, Kosynskyi was sent on a three-year business trip abroad to improve his scientific knowledge. He worked at universities and libraries in Paris, Berlin, London and Dresden, where he collected material for a dissertation 
on credit theory. He paid special attention to the theory of cooperative credit. Subsequently, he chose cooperation as his specialty and studied at a number of foreign cooperative organizations. For more than a year, Kosynskyi worked at the Library of the British Museum. Credit cooperatives, at that time, significantly discovered their potential in the West to support small-scale manufacturing and the rise of agriculture, especially peasant economy. The research resulted in a master's thesis 'Institutions for small loans in Germany. Their history related to some aspects of the economic life of this country' (Kosinskii, 1901), which was defended in 1900 (Eliseva \& Dmitriev, 2011).

Upon returning to Moscow, the scientist continued to work at the university, since 1900 as a private associate professor at the Department of Political Economy and Statistics, where he lectured on industrial economics (Kosynskyi, 1998).

In 1901, Kosynskyi was sent to the Riga Polytechnic Institute (RPI), to alleviate the shortage of specialists in political economy at the time. The first period of Kosynskyi's stay in Riga was not long, but it was considered productive. At first, he was an associate professor, but on January 1, 1902, he was appointed Master of Political Economy. After some time, Kosynskyi held the position of adjunct professor of political economy at the Riga Polytechnic Institute.

While working in Riga, Kosynskyi worked on his doctoral dissertation on agriculture and became acquainted with the local agrarian system, according to which most of the agricultural land belonged to German barons. He considered the system unfair and inaccurate from an economic point of view and, in his opinion, Latvian farmers should have been large landowners. He never hid his thoughts and, as a result, lost his position at Riga Polytechnic Institute and was forced to move to Odessa (Feigmane, 2017).

After a long time working abroad, in 1904, Kosynskyi finally returned to Ukraine. The scientist's academic interests focused on the problems of economics. Economic theory had been taught in all faculties at Novorossiysk University since it was established. Economic science developed in close connection with the economic development of Odessa, southern part of Ukraine and the country as a whole. The scientific and social work of eminent economists had always focused on the economic problems that the country was facing. Of particular importance in this regard was the period from the mid-1860s to October 1917. In 1861, the abolition of serfdom opened opportunities for development of capitalist tendencies, which for decades determined the scientific interests of economists at Novorossiysk University, whose contribution to the development 
of the economy, culture and education of the city and region was particularly significant. Scientists had studied the role of peasantry in economic development, the future of rural communities, opportunities to enter European markets, competition in the production and export of bread.

Economists were united by the fact that they were highly educated people who mostly considered it their public duty to work for the good of the fatherland. Kosynskyi occupied an honorable place among the economists at the university (Kudinova, 2000).

On March 19, 1904, Kosynskyi was appointed professor of police law at Novorossiysk University. In the spring of 1905 , he went on a summer vacation abroad, and after returning on October 28, 1905, became the dean of the law faculty. At this time, taking into account the revolutionary events, teachers of higher educational institutions intensified protests against the statute of 1884 , according to which all the activities of these institutions were subordinated to the Minister of Education and trustees of educational districts. The faculty of professors was almost deprived of any power to influence university life. To counteract this, in 1905, the Academic Union of Professors was established at Novorossiysk University, with Kosynskyi as one of its members (Horniak et al., 2015).

Professor Kosynskyi was head of the Department of Political Economy at Novorossiysk University during 1905-1909 (Istoriia ta suchasnist, 2015). He was an expert on agrarian relations and a supporter of the capitalist development of the country, the rapid elimination of the remnants of serfdom and redistribution of landed estates (Horkina, 2007). In 1906, he published a monograph 'On the agrarian question. Issue 1. Peasant and landlord economy', in which he put forward the concept of 'recapitalization' of large land holdings and the transfer of land to working families (Kosynskyi, 1906). Kosynskyi defended this work as a doctoral dissertation in 1907 at Moscow University and with the decision of his Academic Council of March 14 was approved for the title of doctor of political economy.

His works 'On the issue of modern agricultural crisis' (1906), 'On the agrarian question' (Kosynskyi, 1906), 'Is agrarian reform possible in Russia without partial expropriation?' (1909) and others of the same direction provoked heated discussions. Studying the state of affairs in agriculture, Volodymyr Kosynskyi concluded that the cultural backwardness of the peasantry is an insurmountable brake on any economic success. To eliminate the backwardness, education, the 
establishment of economic institutions, and the improvement of the legal status of peasants were necessary.

Kosynskyi also developed a theory of statistics, as evidenced by his works such as 'On the methods of scientific development of statistical data' (1890), 'On the question of measures and development of Russia's productive forces. Statistical and economic sketch' (Kosynskyi, 1904). Using huge statistical material, he conducted a comparative analysis of the "technical and economic nature" of peasant and landlord economy with conclusions in favor of the peasants, whose enterprises, according to his research, were more viable and adapted. Kosynsky nevertheless emphasized that under the existing political and cultural conditions, the rational conduct in agricultural production and the solution of the agrarian issue is impossible.

During the Stolypin reaction that followed the defeat in the revolution of 19051907, Kosynskyi was repressed. In July 1908, he was dismissed by the GovernorGeneral of Odessa and removed from his teaching position at Novorossiysk University. Kosynskyi moved to Kyiv, where the Academic Council of the Kyiv Polytechnic Institute elected him extraordinary professor of political economy at the agricultural department of this institute (Kosynskyi, 2015). At the same time, he worked at the Department of Applied Economics of Kyiv Commercial Institute, where he taught, in particular, a course on the history and theory of political economy, and was a member of the Board of the Institute. However, even here, under the orders of the Governor of Kyiv, Kosynskyi remained under secret police surveillance.

The Kyiv period became for Kosynskyi a time of active social and political life. He became a member of the Ukrainian Scientific Society (since 1910) and joined the Constitutional Democratic Party. In 1911, Kosynskyi was approved as chairperson of the professorial disciplinary court. He lectured on economic problems among the Kyiv intelligentsia, and was commissioned to speak at the First All-Russian Agricultural Congress, which took place in fall 1913 in Kyiv.

The first All-Russian Agricultural Congress was organized on the initiative of the Council of the Kyiv Society of Agriculture and Agricultural Industry. Preparatory work for organizing the congress began only on January 25, 1913. The meeting was chaired by agronomist I. G. Chernysh, chairman of the Kyiv provincial Zemsky Assembly.

On September 1, 1913, after a prayer service in St. Sophia Cathedral in Kyiv, 
in the presence of participants and guests, the chairman of the organizing committee for convening the Congress, G. L. Davidov solemnly opened the first general meeting of the First All-Russian Agricultural Congress. The work of the congress was divided into the following sections: 1) social agronomy; 2) economy and organization of agriculture and agricultural industry; 3) economy, social agronomy, agriculture and animal husbandry; 4) animal husbandry; 5) agriculture; 6) gardening and horticulture; and 7) forestry (Serhieieva, 2018). At the congress, Kosynskyi delivered a report titled 'A few words on development in agriculture'.

Before the First World War, in 1913-1914, Kosynskyi travelled on business to Germany, Austria, and Switzerland.

After the February Revolution, he worked at the Chief Land Committee, chaired by $\mathrm{O}$. Posnikov, which had been created by the provisional government to solve land issues, and at the League of Agrarian Reforms organized for the same purpose. The latter included O. Chayanov, M. Kablukov, M. Tugan-Baranovsky and other famous Russian and Ukrainian scientists. In 1917, Kosynskyi published the first part of his fundamental monograph The Main Trends in the Mobilization of Land Ownership and Their Socio-Economic Factors: On the Agrarian Issue, Part 1: Land Debt, and was working hard to complete it. In 1918, the second part of the monograph, Mobilization of Land Ownership, was published. In October 1917, Kosynskyi was elected a member of the Provisional Council of the Russian Republic from the Constitutional-Democratic (or Kadet) Party (Volobuev, 1993). Next to economic problems, Kosynskyi drew attention to the issue of organization of science, which led him to the circle of intellectuals who formed a commission in the summer of 1918 to draft a bill on the establishment of the Ukrainian Academy of Sciences under Volodymyr A. Vernadsky (Matvieieva, 1998). Kosynskyi took part in its meetings, where the structures and the charter of the future academy were worked out. At the end of its work in October 1918, the said commission recommended him as one of the first academicians, to join the 12 most authoritative specialists in three departments-history and philology, physics and mathematics, and social studies. Volodymyr A. Vernadsky joined the latter department along with such well-known specialists as M. I. Tugan-Baranovsky and O. I. Levitsky (Kosynskyi, 2018).

Kosynskyi took part in the first constituent general meeting of the Ukrainian Academy of Sciences on November 27, 1918 (Palii, 2013). He actively worked at the next two general meetings of the Academy, held on November 30 and December 7. Since November 16, 1918, Kosynskyi combined the duties of 
academician with the position of Minister of Labor in the government of Hetman Pavlo Skoropadsky. This was forbidden, so he participated at the meeting of the Ukrainian Academy of Sciences until December 1918, after which he voluntarily refused to reward the academician, because on November 20,1918, a law was passed on the right to concurrently hold the positions of an academician and minister without receiving an academician's salary. On the day the law on the existence of the Ukrainian Academy of Sciences was adopted, on November 16, 1918, an order was published in the State Gazette approving Kosynskyi as Minister of Labor. This step greatly hindered not only his scientific activities, but later also affected his entire destiny. After the directorate came to power, the scientist was stripped of his rights. Kosynskyi continued to be persecuted after the arrival of the Bolsheviks in Kyiv in early 1919, and was forced into hiding. Only at the personal request of the UAS and V. A. Vernadsky and A. Yu. Krymsky in the summer of 1919, the Soviet People's Commissar of Ukraine allowed Kosynskyi to resume his duties, along with other scientists from the Polytechnic Institute. In May 1919, the Council of the Polytechnic Institute sent a letter to the chairman of the Council of People's Commissioners (SNC) of the USSR with a request to release the prominent scientist V. Kosynskyi from persecution. At the same time, the Ukrainian Academy of Sciences sent its petitions. The letter of the Presidium of the Academy signed by its president, Vernadsky, stated that Professor Kosynskyi was an outstanding economist and, in particular, one of the experts on peasant land tenure and economy. His scientific, teaching and practical work is especially valuable for explaining and developing complex and difficult issues that arise in Ukraine's economic life (Vernadskyi, 2011).

The next period of Kosynskyi's life, which is associated with Odessa, is the least studied one in the scientist's biography. It is known that in the summer of 1919, the People's Commissar of Ukraine allowed Kosynskyi to resume his duties. According to archival sources, in December 1919, Kosynskyi worked as a teacher of statistics at the Odessa Polytechnic Institute. An excerpt from the Minutes of the 1st meeting of the Faculty of Economics of the OPI of January 2, 1920 reveals that on January 1, Kosynskyi was elected full professor of the Department of Statistics of the Odessa Polytechnic Institute. In the spring semester, he was instructed to teach a general course on statistics for up to 8 hours per week (Hrushytska, 2017). In the report from March 4, 1920 of the Dean of the Faculty of Economics, V. M. Tverdokhlebov to the board of the institute, Kosynskyi is also mentioned as professor of statistics. On April 10, 1921, the Minutes of the 10th meeting of the Special Mobilization Commission for the Accelerated 
Graduation of Economists discussed the question "Of the lecturer who teaches the course Agricultural Economics in Relation to Agricultural Areas instead of V. A. Kosynskyi, who has left". This gives grounds to claim that Kosynskyi was in Odessa at least until March 1921, and did not leave for Warsaw in 1919, according to some researchers. Upon the decision of the joint meeting of UAS, Kosynskyi was sent from Odessa to Kamyanets-Podilsky University free of charge. Hence, on the eve of the faculty "cleansing" in 1921-1922, Kosynskyi managed to go abroad (Eliseva \& Dmitriev, 2011, p. 211). At first he was in Warsaw, but due to the difficult political situation, in 1922, Kosynskyi moved to Constantinople, and then to Prague, where a new stage in his scientific and pedagogical activities began. It was known that during this period the Czechoslovak government in the person of T. Masaryk (1850-1937) and K. Kramarz (1860-1937) was very active in supporting Russian emigrants, creating favorable conditions for their living, and scientific and pedagogical activities (Eliseva \& Dmitriev, 2011).

In Czechoslovakia, Kosynskyi lived in Prague and taught at the Russian Free University, the Russian Faculty of Law at Charles University, the Commercial College, the Russian Institute of Agricultural Cooperation, and the Ukrainian Academy of Economics in Podebrady.

In 1928, Kosynskyi was expelled from the All-Ukrainian Academy of Sciences on the grounds of lack of information about him. In fact, Kosynskyi moved to Riga, where he had already worked in the early twentieth century. On May 24, 1928, at a meeting of the Faculty of Law, Kosynskyi was elected an untenured professor for five years, although he was still living in Prague at the time. On June 28, 1928, the Cabinet of Ministers approved him being elected as an untenured professor at the University of Latvia, and he was counting on this position as of July 1. On August 25, 1928, the Consulate General of Latvia in Czechoslovakia issued entry visas to Volodymyr Kosynskyi, his wife and two children. When they arrived in Latvia, they were issued identity cards (Kosynskyi, 1998). The Kosynskyi family settled in Pardaugava, in a small apartment on Lapu Street. The university's leaders instructed Kosynskyi to conduct a seminar on economic theory and economic geography. In 1932, Kosynskyi was unanimously elected a state professor at a meeting of the Faculty of Economics and Law. In addition, at the professor's request, the faculty gave him the right to give lectures in the German language, although only Latvian was approved as the language for lectures and seminars. Kosynskyi was fluent in Russian, German, French, English and Italian.

Kosynskyi was not only a scientist but also a teacher. While teaching political 
economy at the University of Riga, he published his lecture notes Fundamentals of Political Economy in Latvian.

Kosynskyi died on November 5, 1938 and is buried in the Pokrov (Intercession) Cemetery in Riga.

The obituary on Kosynskyi's death reveals that he was one of the people who are always and high above all in the service of science, knowledge and the enlightened ideals of humanity ('Umer Prof. V. A. Kosinskii', n.d.).

After Ukraine became independent, Volodymyr Kosynskyi was named one of the founding academicians of the National Academy of Sciences of Ukraine, thus restoring his legacy.

To conclude, Kosynskyi's life and creative path could be divided in several periods.

The first period, 1864-1883, included his birth, childhood, studies in the gymnasiums of Hlukhiv and Novgorod-Seversky in Ukraine.

1883-1901 was a Moscow period, when he studies and taught at Moscow University. In the course of this period, he travelled extensively in Europe for three years (from 1895 to 1898).

1901-1904 marked the first Riga period, which involved his teaching political economy at Riga Polytechnic Institute.

This period was followed by two Odessa periods. The period from 1904 to 1908 is associated with his work at Novorossiysk University. The second period, from late 1919 to early 1921, was filled with scientific and pedagogical activities at the Odessa Polytechnic Institute.

During the two Kyiv periods, he was professor at the Department of Political Economy of the Kyiv Polytechnic Institute (since 1909); Minister of Labor in the Council of Ministers of the Ukrainian state (1918); and a teacher at the Kamyanets-Podilsky Institute of Public Education (1921).

The years 1922-1928 mark the Prague period, when he was mainly involved in teaching.

Finally, the second Riga period lasted from 1928 to 1938, during which he worked as a professor at the University of Latvia. 
In the person of Volodymyr Andriyovych Kosynsky, Ukraine lost an outstanding specialist in the field of political economy, finance and agricultural economics. Kosynskyi studied the economic problems of agriculture, and observed the trends and issues in agrarian development. These observations gave him the opportunity to suggest ways to reform agriculture, to justify the leading role of cooperative credit in its development, show the potential of the credit system to influence economic crises, and draw attention to the need to study the psychological origins of economic phenomena. Kosynskyi proposed a number of concepts and theories that became the crux of future scientific research. He stressed the expediency and possibilities of applying statistical research in various spheres of public life. His scientific legacy is still waiting to be studied by researchers.

The fate of Kosynskyi was inextricably linked with the historical events of his time. The last period of his life and career is that of a well-known scientist who was born and worked in Ukraine and is associated with Latvia, a country that gave him the opportunity to live and work when it was impossible in his homeland. Throughout his pedagogical activities, Kosynskyi contributed to the training of highly qualified specialists_-Latvian economists, who were later prolific contributors to various sectors of the economy. He also made a significant contribution to the development of Latvian and European economics.

The share of Volodymyr Kosynskyi's research clearly testifies that the scientific activity of people from Ukraine contributed to the entry of Ukrainian science into the European scientific community long before the country gained independence. The scientific activity of Ukrainian scientists in the early twentieth century created a solid foundation for a scientific cooperation with European scientists, which is of fundamental importance at the present stage, as European integration processes are Ukraine's priorities as an independent country. 


\section{References}

Bielashov, V. I. (2011), 'Orhanizatsiia navchalnoho protsessu i personalnyi sklad vykladachiv hlukhivskykh cholovichoi ta zhinochoi himnazii u 1870-kh - 1920-kh rokakh u spohadakh vykladacha V.A. Malchenka' [Memoirs of V. A. Malchenko on the organization of the educational process and staff composition of teachers in the Hlukhiv men's and women's gymnasiums in 1890s-1920s], Sivershchyna $v$ istorii Ukrainy [Siveria in the history of Ukraine], vol. 4, pp. 361-365.

Eliseva, I. I. \& Dmitriev, A. L. (2011), 'V. A. Kosinskii - vidnyi otechestvennyi statistik i economist' [V. A. Kosinskii - the prominent local statistic and economist], Voprosy statistiki, no. 4, pp. 76-81.

Feigmane, T. (2017), 'Profesora Vladimira Kosinska (1864-1938) dzīves un darba gaita' [The life and work of Professor Volodymyr Kosinski (1864-1938)], Inženierzinātņu un augstskolu vesture [History of engineering sciences and institutions of higher education], vol. 1 (2017), pp. 67-78. https://doi.org/10.7250/IAV.2017.004

Horkina, L. P. (2007), 'Akademik V. A. Kosynskyi: suchasnyi pohliad na zhyttievyi shliakh ta naukovu spadshchynu ukrainskoho vchenoho' [Academician V. A. Kosynskyi: a lucky glance at his life and science in Ukraine], in L. P. Horkina (ed.) Istoriia narodnoho hospodarstva ta ekonomichnoi dumky Ukrainy: zb. nauk. prats., Kyiv: IEP NANU, nos. 39-40, pp. 206-236.

Horniak, O. V.; Dolenko, L. Kh. \& Lomachynska, I. A. (2015), 'Rozvytok ekonomichnoi teorii v Odeskomu universyteti: doslidzhennia i personalii’ [Development of economic theory at the University of Odessa: advances and personalities], in I. M. Koval (ed.) Nauky pro suspilstvo: ekonomika, pravo, menedzhment, politolohiia: yuvileina zbirka naukovykh prats, prysviachena 150-richchiu Odeskoho natsionalnoho universytetu imeni I. I. Mechnykova, Odessa: Odeskyi natsionalnyi universytet imeni I. I. Mechnykova, pp. 330-341. Retrieved from http://fs.onu.edu.ua/clients/ client11/web11/pdf/uv-zbir-150.pdf [accessed Mar 2021]

Hrushytska, I. B. (2017), 'Akademik V.A. Kosynskyi - vykladach statystyky ekonomichnoho fakultetu Odeskoho politekhnichnoho instytutu' [Academician VA Kosynskyi - a lecturer in statistics at the Faculty of Economics of the Odessa Polytechnic Institute], in Problemy i perspektyvy innovatsiinoho rozvytku ekonomiky $v$ konteksti intehratsii Ukrainy $v$ Yevropeiskyi naukovo-innovatsiinyi prostir: materialy XXII Mizhnarodnoi naukovo-praktychnoi konferentsii, vol. II (Odesa, 11-13 ver. 2017 r.), Kyiv: Feniks, pp. 12-16. Retrieved from https://economics.opu.ua/files/science/ probl_innov_rozv/2017/t2/12.pdf [accessed 16 Jan 2020]

Istoriia ta suchasnist (2015), Odeskyi Natsionalnyi universytet imeni I.I. Mechnykova. Istoriia ta suchasnist [A humorous story: Odessa I. I. Mechnikov National University], Odessa, ONU, pp. 224-225.

Kosinskii, V. A. (1890), O priemakh nauchnoi razrabotki statisticheskoi dannykh [On scientific methods and development of statistical data], Moscow: Tipo- 
litografiia D. A. Bonch-Bruevicha. Retrieved from https://biblioclub.ru/index. php?page=book\&id=110353 [accessed Mar 2021]

Kosinskii, V. A. (1901), Uchrezhdeniia dlia melkogo kredita v Germanii. Ikh istoriia v sviazi s nekotorymi storonami ekonomicheskoi zhizni etoi strany [Small loan institutions in Germany. Their history in connection with some aspects of the economic life of this country], vol. 1, Moscow: Univ. tip. Retrieved from http://e-heritage.ru/ras/ view/publication/general.html?id=47406140 [accessed Mar 2021]

Kosynskyi, V. A. (1904), K voprosu o merakh $k$ razvitiiu proizvoditelnykh sil Rossii: Statistikoekonomicheskii eskiz [On the issue of measures for the development of Russian production strength: Statistical and economical sketch], Odessa: "Ekon." tip.

Kosynskyi, V. A. (1906), K agrarnomu voprosu: Vyp. 1. Krestianskoe y pomeshchyche khoziaistvo [On the agrarian issue: Vol. 1: Peasant and landlord economy], Odessa: "Ekon." tip. Retrieved from http://e-heritage.ru/ras/view/publication/general. html?id=48289771 [accessed Mar 2021]

Kosynskyi, V. A. (1913), 'Dekilka sliv z pryvodu evoliutsii v silskomu hospodarstvi: dopovid' [A few words about the evolution of agriculture: a report], in Trudy I Vserosiiskoho silskohospodarskoho zizdu v m. Kyievi 1-10 veresnia 1913 h, Kyiv.

Kosynskyi, V. A. (1998), Profesory Natsionalnoho tekhnichnoho universytetu Ukrainy, Kyivskyi politekhnichnyi instytut [Professors of the National Technical University of Ukraine Kyiv Polytechnical Institute], Kyiv: Osvita.

Kosynskyi, V. A. (2013), 'Personalnyi sklad' [Personal files], in V. M. Palii \& Yu. O. Khramov (eds.) Natsionalna akademiia nauk Ukrainy 1918-2013, Tsentr doslidzhen naukovo-tekhnichnoho potentsialu ta istorii nauky im. H. M. Dobrova NAN Ukrainy, Kyiv: Feniks, p. 51.

Kosynskyi, V. A. (2015), 'Vladimir Kosynskyi: Biohrafiia' [Vladimir Kosynskyii: A biography], Natsionalnoho tekhnichnoho universytetu Ukrainy "Kyivskyi politekhnichnyi instytut". Retrieved from https://kpi.ua/ru/kosynsky-about [accessed Mar 2021]

Kosynskyi, V. A. (2018), 'Pershi akademiky (diisni chleny) Ukrainskoi Akademii Nauk' [The first full members of the Ukrainian Academy of Sciences] in Do 100-richchia Natsionalnoi akademii nauk Ukrainy : naukovo-dopomizhnyi biobibliohrafichnyi pokazhchyk, Derzh. nauk.-tekhn. b-ka Ukrainy, Inform.-bibliohr. Kyiv: DNTB Ukrainy, pp. 97-105.

Kryzhanivskyi, V. M. (2017), 'Vasyl Andriiovych Malchenko ta yoho spohady pro Hlukhiv ta hlukhivchan za 1870 - 1930 rr.' [Vasyl Andriiovych Malchenko and his memoirs about Hlukhiv and Hlukhiv residents in 1870-1930], Istorychni studii suspilnoho prohresu [Historical studies of social processes], vol. 5, pp. 356-310.

Kudinova, L. Iu. (2000), 'Kosynskyi Volodymyr Andriiovych,' V. A. Smytyna (ed.) Profesory Odeskoho (Novorosiiskoho) universytetu: Biohrafichnyi slovnyk, vol. 3: K-P, Odessa: Astroprynt, pp. 123-124. 
Masliichuk, V. (2016), “"V horode malomъ, nahornomъ, zdorovomъ, krasyvomъ y kak bы odnoi hymnaziy prynadlezhashchemъ” (Novhorod-siverske uchylyshche (himnaziia) kintsia XVIII - pochatku XIX st.)' [In a small, beautiful, healthy city, as if belonging to one gymnasium" (Novgorod-Seversky school) (gymnasium) late 18th to early 19th century], Siverianskyi litopys, vol. 6, pp. 162-174. Retrieved from http://nbuv.gov.ua/UJRN/ [accessed Mar 2021]

Matvieieva, L. V. (1998), 'Akademik Volodymyr Kosynskyi,' in Chleny-zasnovnyky Natsionalnoi Akademii nauk Ukrainy. Z $b$. narysiv [Founding members of the National Academy of Sciences of Ukraine. Collection of essays], Kyiv: In-t istorii Ukrainy NAN Ukrainy, pp. 323-324.

Miroshnichenko, Yu. R. \& Fedirko, A. M. (2014), Novhorod-Siverska himnaziia - alma mater Siverskoho kraiu (1808-1918) [Novgorod-Seversky Gymnasium - the alma mater of the Siverian region (1808-1918)], Kyiv: Feniks.

Morozov, V. V. (2011), 'Vnesok dvorianstva Livoberezhnoi Ukrainy v stanovlennia ta rozvytok arkhivnoi spravy poreformenoho period' [The role of nobility in the LeftBank Ukraine in the formation and development of archival studies in the postreform period], in V. V. Morozov (ed.) Istorychnyi arkhiv. Naukovi studii: Zb. nauk. pr., Mykolaiv: ChDU im. Petra Mohyly, pp. 130-132.

Palii, V. M. (2013), 'Personalnyi sklad' [Personal files], in V. L. Bohdanov (ed.) Natsionalna akademiia nauk Ukrainy 1918, Kyiv: Feniks.

Ruda, O. V. (2010), 'Kozatske povstannia pid provodom Kryshtofa Kosynskoho v interpretatsii polskykh istorykiv kintsia XIX - pershoi tretyny XX stolittia' [Cossack uprising under the lead of Kryshtof Kosynskyi according to the interpretation of Polish historians at the end of the 19th to first third of the 20th century], Chornomorskyi litopys, vol. 2, pp. 132-140. Retrieved from http://nbuv.gov.ua/ UJRN/Chl_2010_2_22 [accessed Mar 2021]

Serhieieva, I. L. (2018), '1-i Vserosiiskyi silskohospodarskyi zizd u diialnosti ta tvorchii spadshchyni B. K. Yenkena' [The First All-Russian Agricultural Congress in the activities and creative legacy of B. K. Yenken], Istoriia nauky $i$ tekhniky, vol. 8, no. 1(12), pp. 228-232.

https://doi.org/10.32703/2415-7422-2018-8-1(12)-228-232

Tovmachenko, V. M. (2012), 'Vydatni vcheni-ahrarii periodu stanovlennia ta rozvoiu Ukrainskoi akademii nauk (1918-1931)' [Outstanding agricultural scientists in the period of formation and development of the Ukrainian Academy of Sciences (1918-1931)], Visnyk ahrarnoi istorii, no. 3, pp. 220-231.

'Umer professor V. A. Kosinskii' (n.d.), [Professor V. A. Kosinskii has died], Besedy o Rige. Retrieved from /http://forum.myriga.info/index.php?act=Attach\&type=post\&id= 7792 [accessed Mar 2021]

Vecherskyi, V.V. (2005), Pamiatky arkhitektury y mistobuduvannia Livoberezhnoi Ukrainy: Vyiavlennia, doslidzhennia, fiksatsiia: Monohrafiia Derzh. sluzhba okhorony kulturnoi spadshchyny [Monuments of architecture and urban planning of the Left Bank of 
Ukraine: Violation, research, fixation: Monograph of the State Cultural Heritage Protection Service], Kyiv: Naukovo-doslidnyi instytut pamiatkookhoronykh doslidzhen.

Vernadskyi, V. I. (2012), Lystuvannia z ukrainskymy vchenymy [Correspondence with Ukrainian scientists], NAN Ukrainy, Komisiia z naukovoi spadshchyny akad. V. I. Vernadskoho, Nats. b-ka Ukrainy im. V. I. Vernadskoho, In-t istorii Ukrainy, vol. 2, Kyiv. Retrieved from http://irbis-nbuv.gov.ua/everlib/item/er-0002165 [accessed Mar 2021]

Volobuev, P. V., ed. (1993), Politicheskie deiateli Rossii, 1917: biograficheskii slovar [Russian Political Figures, 1917: Biographical dictionary], Tsentr polit. i ekon. istorii Rossii Ros. nezavisimogo in-ta sotcial. i natc. probl., Nauch.sovet Ros. AN po probl. "Istoriia revoliutcii v Rossii", Moscow: Bolshaia ros. entcikl., p. 388.

Lyubov Sukhoterina, PhD is a professor at the Department of Philosophy and Methodology of Science of Odessa National Polytechnic University. Sukhoterina graduated from the Faculty of History of Odessa I. I. Mechnikov State University. In 1984, she defended her dissertation for the degree of Candidate of Historical Sciences. Since 1984, she has been working at the Odessa National Polytechnic University, starting as a senior lecturer, then as an associate professor (1989), from 2000 to 2021 as head of the Department of Political Science. In 2005, she defended her dissertation for the degree of Doctor of historical sciences. In 2007, Sukhoterina was elected an academician of the Academy of Higher Education of Ukraine, in 2008 by the decision of the Certification Board of the Ministry of Education and Science of Ukraine she was awarded the academic title of professor. Her areas of scientific interests are the creation and functioning of scientific schools, which were formed by well-known specialists in the field of technical sciences in the 1920-1930s in Ukraine. She has published more than 100 scientific papers. 